CATALAN REVIEW

Catalan Review

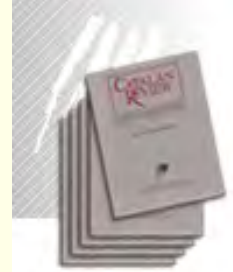

You are accessing the Digital Archive of the Catalan Review Journal.

By accessing and/or using this Digital Archive, you accept and agree to abide by the Terms and Conditions of Use available at http://www.nacs-

catalanstudies.org/catalan review.html

Catalan Review is the premier international scholarly journal devoted to all aspects of Catalan culture. By Catalan culture is understood all manifestations of intellectual and artistic life produced in the Catalan language or in the geographical areas where Catalan is spoken. Catalan Review has been in publication since 1986.
NORTH

AMERICAN

CATALAN

SOCIETY
Esteu accedint a l'Arxiu Digital del Catalan Review

A l' accedir i / o utilitzar aquest Arxiu Digital, vostè accepta i es compromet a complir els termes i condicions d'ús disponibles a http://www.nacs-

catalanstudies.org/catalan review.html

Catalan Review és la primera revista internacional dedicada a tots els aspectes de la cultura catalana. Per la cultura catalana s'entén totes les manifestacions de la vida intel lectual i artística produïda en llengua catalana o en les zones geogràfiques on es parla català. Catalan Review es publica des de 1986.

\title{
Fact to Fiction: Catalan History retold Kathleen McNerney
}

Catalan Review, Vol. XV, No. 2 (2001), p. 137-145 


\title{
FACT TO FICTION: \\ CATALAN HISTORY RETOLD
}

\author{
KATHLEEN MCNERNEY
}

In recent Catalan literature, women have had an important voice as an increasing number of new writers win prestigious prizes in all genres. At the same time, the genre of the historical novel, or basedon-fact fiction, has reinterpreted some key points in Catalan history. I'll begin by mentioning a few of the best examples of the retelling of historical events in several novels and stories by contemporary Catalan women writers, and then move to less fictional accounts of events surrounding the Spanish Civil War.

I find no need to go over the parameters of history/narrative again, since this has been so well done by David Herzberger in Narrating the Past: Fiction and Historiography in Postwar Spain (1995), who quotes E. L. Doctorow in his introduction asserting that "There's no more fiction or nonfiction, there's only narrative," Carmen Martin Gaite's Usos amorosos de la postguerra española (1987), especially taken together with her 1978 masterpiece El cuarto de atrás, is particularly instructive as well, and for exile writings, I find Michael Ugarte's Shifting Ground:Spanish Civil War Exile LIterature (1989) most useful.

The following narrations tell of the past in ways that differ strikingly from the "official" version of history.

Carme Riera's Dins el darrer blau (1994) traces the persecution of the Jewish community in Mallorca in the 17th century. Nearly two hundred years after the expulsion from the Peninsula, cryptojews continued to struggle to hold on to their beliefs and keep their communities together. The Spanish Crown, now realizing that further expulsion of members of the mercantile class was economically unwise, did not allow emmigration, but some groups did escape, usually to Italy. Those who didn't make it and didn't recant were at risk of being burned at the stake by the Inquisition. Riera creates a rich fictional work based on extremely well-researched data. In her "Nota de l'autora" at the end of the novel, she explains the two sides of her use of history, in terms of actual recorded events on the one hand, and a re-creation of a specific time and place, on the other. With respect to the first, she remarks:

He canviat noms, cognoms i malnoms a posta per remarcar que el meu llibre no és d'història, sinó de ficció. En els dominis de la història cap material no pot ser manipulable; en el de la novel-la, per molt històrica que sigui, mentre es 
mantingui la versemblança, la veritat de cohesió, tot és vàlid i és legítima, en conseqüència. (430-3i)

And continuing on to the building of an atmosphere within which to place the events, essential for a story so far removed from the surroundings of a current reader, she continues:

He procurat, evitant els anacronismes, donar al lector les pautes suficients perquè pogués entendre com visqueren i moriren els criptojueus mallorquins a finals del segle XVII, com foren les seves cases, els seus costums, quins oficis tenien, i com alguns d'ells mantenien aliances amb els nobles en els negocis de mar - el cors - que enriquiren bona part de la noblesa mallorquina. (431)

Dins el darrer blau, which I consider Riera's masterpiece so far, is her second incursion into matters of the Holy Office: in an early, eerie tale with an appropriately baroque title, "La senyoreta Ângels Ruscadell investiga la terrible mort de Marianna Servera, ${ }^{0}$ an investigative reporter doing research on the Inquisition finds herself in a compromising position with an elderly man. He had promised to give her historical fact, but only recreates his own erotic fantasy involving a young woman who was burned at the stake by his medieval ancestor. Parallels between the "witch" and the reporter are inevitable. And finally, like so many postwar writers, Riera addresses herself to the aftermath of the Civil War in a tender story called "Helena, Helena," which is dedicated to J. F. M. and "tots els exiliats del meu país." (27) In it, a woman separated from her husband during the war finds that he is alive years later, after she has begun a happier relationship with another man.

Isabel-Clara Simós Júlia (1983) has the nineteenth-century labor strife in Valencia as a background for a Cinderella story gone sour. The desperation of the workers whose jobs were being replaced by machines develops into strikes and bloody repressions of the workers in the textile-producing town of Alcoi. The marriage of a lower class woman to the boss does little to improve the lot of the laborers and ends up demoralizing the princesslike protagonist. In an intriguing paper with the delicious title "Rage Against the Machine-History Disobeyed, Justice Delayed and Cinderella Spayed," Patricia Hart peels back various layers of the rewriting of history in this complex work: "...we hear the sounds of the traditional Easter celebration with the annual re-enactment of the reconquest of Alcoi in a symbolic battle between Christians and Moors." (174) In alluding to religious intolerance, racial strife, and social division, Simó also recalls Franco's contrived identification with an even earlier "reconqueror," Ruy Diaz de Vivar, "El Cid" - an essential part of the Galician general's propaganda. Herzberger has shown how Franco's wish to return to 
an idealized medieval period in order to control and manipulate a more recent history creates a vision of the Caudillo leading a modern Reconquest to save Spain from a new brand of Infidels - the Reds. Hart compares the Civil War Leftists with their nineteenth-century counterparts, the Alcoi anarchists, whose history of brutal repression forms some of the roots of the bloody conflict of the r93os. She concludes that Simó's novel "must necessarily be read as a frontal attack on Francoist historiography" (174) even though all the action takes place in the nineteenth century. Here, the history of the labor movement in Alcoi, juxtaposed with various kinds of fairy tales, leads to the uncovering of truths both individual and societal: what in María de Zayas is a "desergaño," the ending of an "engaño." In both periods, various modern versions of fairy tales were dished out by the conservative Catholic males of the ruling class, whether these were manifestations of a controlled popular culture or official discourses from pulpit or throne. Júlia-Cinderella succeeds, technically, in this novel, but Simó exposes that success for the failure it really is while smashing the various paradigms that lead to it. As both the official story and its fictional counterparts are descroyed, the "real" story we are left with is a female/feminist assessment of history and ethics, of literature and propaganda, an individual life story narrated as a morality tale within a rewriting of social history. Júlia's failure and unhappiness point to her lack of role models, either male or female, individual or societal, and I think Simó deliberately demonizes or vilifies nearly everyone around the would-be heroine. The real female voice is that counterpart of the heroines of Fuenteovejuna, a collective or chorus that tells the truth and takes things into their own hands, so to speak: the rebellious women of Alcoi who castrate their reprehensible mayor. The novel ends with a dire scene of Júlia throwing a sizzling "truita" at her evil but helpless old mother-in-law: both women have been victims and executioners in different ways and times. Simó doesn't let them off the hook: in spite of their victimization and powerlessness within the dominant culture, they make choices that go along with their oppressors, they collaborate in oppressing orhers, and the egg in the face metaphor says it beautifully.

Anna Murià's Aquest serà el principi (I986) tells the story of Republican intellectuals resisting Franco's attack, living the madness of the war, and finally going into exi!e. Many of the characters in the novel are thinly disguised historical figures such as anarchist Andreu $\mathrm{Nin}$; in the prologue, she identifies Nin with her character Haima. Since she did not know him personally, she mythifies him, making him into the legend he became, partly because of his untimely and mysterious death. In a I995 interview, Murià also identified the novel's Berta with her friend during exile, novelist Mercè Rodoreda. Most 
intriguing, though, is Murià's recreation of herself, both as one of the characters and as a metamorphosing narrator, sometimes omniscient, sometimes first person, sometimes plural or collective, and once in a while interjecting her own authorial comments into the narration. Early in the novel she switches abruptly from one of several complicated love relationships into a political history with Barcelona as protagonist: "Per damunt de les històries individuals, s'estremeix poderós el gran entrellat del cor de tots, adolorit, combatiu i roent dins aquell febrer d'aire gèlid que sembla un estiu. La història d'un poble." (54) And on a couple of occasions, the author seems to apologize for her own handling of the narration, particularly with respect to the passage of time: "Veig que avanço i retardo situacions, que salto enrera i endavant, que barrejo el temps, que esbullo els fulls del calendari...La previsió pot tenir calendari, però no l'evocació." (280) At the end of the novel, she weaves a similar accounting of her modus operandi together with an explanation of the book's title: "M'adono que el teixit d'aquesta història que he volgut reconstruir queda una mica esfilagarsat...En el meu teixit no aconsegueixo l'acabat. La vida és, tanmateix, esfilagarsada...Si cada gest, cada pensament, cada minut són preludi d'un nou temps que comença..." (380). As Michael Ugarte points out, her use of the metaphor of weaving is particularly apt, bringing together a history of feminine story-telling as old as Greek mythology with Murià's own experience that life is not a closed system, not a story with a neat beginning, middle and end, but rather, as Ugarte puts it, a series of "impressions that appear woven into a fabric. They are loose ends that lead us constantly into a beginning." (138) In the prologue, Murià elaborates the long gestation of this novel and its many revisions over a period of forty years, and answers the inevitable question:

Ja és ben sabut que totes les novel-les de tots els autors són autobiogràfiques...Sí, és autobiogràfica. Els fets històrics són vistos per mi. Reconec actes i sentiments personals meus almenys en tres de les protagonistes, però poc o molt hi ha quelcom de mi en totes les figures, inclús les masculines. I sí, a part de jo mateixa, hi hagueren models reals per a la plasmació dels personatges i per al brodat de l'anècdota..." (12)

Maria Aurèlia Capmany brings many diverse periods together in her novel narrated as a fanciful biography, Quim/Quima (1983), in which she presents a whimsical overview of Catalan history from the middle ages to the end of the Spanish Civil War. In the prologue, Capmany pays tribute to Virginia Woolf's Orlando (1928) and calls it a "calc" for her own work. While Quim/Quima has no precise date for either birth or death, he/she passes through specific periods of Catalan history, participating more actively as male than as female. 
While the time frame becomes vague at some points, there are dates and episodes that are clearly identifiable and listed in a chronological table at the end. Quim first appears as a child of 8 in the year 1000 when fear of the end of the world sweeps across Europe; at 12 in roro he joins the expedition of Ramon Borrell to fight against one group of Moors on behalf of another; he's 25 in 123 I when he saves the Cathar treasure only to lose it to the Templars. As the thirteenih century goes along, he meets Ramon Llull and Jaume the First. The transformation into womanhood takes much longer than Orlando's week of sleeping; much of Quima's time in the ensuing centuries is taken up with such things as love and lawsuits, and her next brush with Catalan history is when she flees Barcelona in $17 \mathrm{I} 4$ as a result of the War of Spanish Succession. As a male again, Tinent Quim Bonfill becomes involved in the Carlist Wars and a rebellion against the military that sends him in exile to Mexico, and the novel ends back in Barcelona as he pilots a "xato" for the republicans in 1938. Capmany is drawn to tangents of race, class, and the survival of her culture, blending together her feminist and nationalist outlook in this metahistorical narration. In Lo color més blau (1982), written a decałe later, Capmany creates an epistolary novel with a specific focus on the aftermath of the Spanish Civil War as seen through the eyes of two women letter writers. Bearing the subtitle "Dos destins de dona separats el gener del 1939," the stories are told in two major voices with minor keys adding depth and texture. The two women, only fifteen when the war separates them, represent two types of war victims: the daughter of militant communists who must go into exile, and the daughter of a middle class family who stays behind. The letters correspond to three periods, ending in 1968, and alternate between Barcelona and various points of European exile. In a somewhat disingenuous disclaimer, between irony and defiance, Capmany inserts a foreword to introduce the novel:

Personatges i fets d'aquesta novel-la són pura invenció. Si s'hi esquitlla alguna dada històrica rigorosament documentada, com és ara l'entrada dels anomenats Nacionals a Barcelona o la parada de l'exèrcit soviètic a l'altra banda del Vistula, puc assegurar que s'hi introdueixen contra la meva voluntat. (unnumbered 9)

Teresa Pàmies explores multiple layers of exile and marginalization in her prize-winning novel Rebelión de viejas (1989), which was written in Castilian and in that sense does not belong with the other works I address here. Nevertheless, I would like to say a few words about it because of its memoir-like quality and of course Pàmies wrote volumes of chronicles in both Citalan and Castilian. The two 
old ladies of the story seem anything but rebellious as the action begins. The Catalan and the Venezuelan met and became friends in the I940s during a political exile in Mexico and then returned to their respective countries. The novel takes place in the eighties when Dora visits her "amiga del alma" in Barcelona rather suddenly, and as the two reminisce it becomes apparent that Dora's new form of exile is from her family, who tries to use her for their own purposes. The nameless Catalan protagonist, who sounds so much like Pàmies that I feel justified in calling her Teresa, returns the visit and also finds herself marginalized from what she wants to do by Dora's overbearing relatives. In spite of the serious subject matter - terrorism and drug trafficking as well as aging and powerlessness - the work has a delightful humor based principally on dialogue. The book is dedicated "A Luisa, de su amiga del alma, T.P." (unnumbered 5) I am convinced that the tone of the conversations, especially the contrast between the speech of the Venezuelan, peppered with diminutives and terms of endearment, and the austere and distanced replies of the correct Catalan, respond to Luisa and Teresa. The narrator, first person for the most part, refers to herself in the third at times, and calls herself "la anfitriona" and "la catalana." The answers the Venezuelan gives to the Catalan lead to a solution through solidarity and refusal to be manipulated or utilized by family, friends, political parties, or anyone. Dora closes the argument as well as the novel in her typical choice words: "Se le ve el tramojo - exclamó Dora- a mí no me embojota la gringuita. Soy vieja pero no pendeja." (197)

Two lyrical novels use the technique or re-creating a life based on historical documents: the novelized biographies by poets Maria Àngels Anglada and Maria-Mercè Marçal strive to resurrect foremothers whose stories they found especially moving. In her prologue, Anglada informs the reader that Les closes (I979) was inspired by her great-grandmother, Dolors Canals, a woman accused of murdering her husband. Since Anglada was living in the same house of l'Empordà once inhabited by her unfortunate ancestor, she looked through the old boxes of papers as well as local archives, and she found a letter from the woman's lawyer explaining the case. This and other documents form a central axis of the book, complemented by reflections and conversations of those around the protagonist. As far as the creation of atmosphere is concerned, the house itself must have been inspirational.

The poet Pauline Mary Tarn (London 1877-Paris 1909), a literary rather than biological foremother of Maria-Mercè Marçal, is the subject of La passió segons Renée Vivien (1995), winner of the Carlemany and Serra d'Or prizes. The two principle axes are files of Sara T., a filmmaker working in the 1980 , and notebooks of Salomó 
R., an erudite Frenchman of the I92os. These and other documents lead the reader through intrigues of the cultural and intellectual society of the 'rive gauche' during the 'belle époque,' a world of hallucinating activity in the fine arts, introducing along the way a number of artists who shared that time and space with Tarn/Vivien. In the "Nota de l'autora" that ends the novel, Marçal makes explicit what the reader suspects: "Tot i que no he inventat cap dels personatges que van envoltar Pauline/Renée ni cap dels episodis de la seva vida, tot això no constitueix sinó un punt de partença, un escarit esquema inicial." (352) The narration offers several differentiated views of the life, spirit, and work of Vivien from friends, lovers, maids, relatives, scholars, and investigators. Marçal uses not only the poetry of her protagonist, but also that of classical poets who inspired her - Sappho, of course, and also Dante - to weave together the rich but brief life of Pauline Tarn. Marçal's own favorites also appear, from Virginia Woolf in the description of transgressors and transvestites to Carme Riera in the evocation of the decadence of the literary nobility, to Quevedo's sonnet 47I, "Amor constante más allá de la muerte." Just as Marçal's own poetry contains a wealth of rhyme, rhythm, and form, the novel is made up of a kind of collage, small pieces, or "trencaclosques a mig fer" (352) as the author describes her own technique. For example, the letters of the Turkish princess Kerimée, solicited by Salomó, form a classic epistolary narrative, whereas the "Monodia final" is pure lyricism, glosses on the poetry of Vivien. The text also includes Marçal's renditions of Vivien's poems, for example the magnificent version of "Plora per mi que per tu ploro," corresponding to "Je pleure sur toi." (II6-I7)

There are a number of memoirs, stricly speaking, about the Spanish Civil War, its aftermath, the concentration camps, and exile written by women. Most of them correspond to the urge to voice, to give a body to the tremendous experiences suffered by the victims, and often they represent a single work of a person who does not consider herself to be a writer, who simply wants to memorialize an event or a person. Frederica Montseny wrote most of her work in Castilian because her political motivation made her strive for the widest possible audience; in Cent dies de la vida d'una dona (1939-40) (1977), she recounts her harrowing trip accross the French border. Cassandra Mestre's single book, Arreu la sorra (1986) is in reality a monument to, and is dedicated to, her brother, executed by Franco after the war. Maria dels Àngels Vayreda presents her Encara no sé com sóc (1985) as a novel, but it seems closer to an autobiography. Quirze Grifell offers Anna Murià: Album de records (1992) as a series of interviews. The work of the couple Josep Travesset and Anna Rosselló fits more into the category of travel literature, with $\mathrm{El}$ més 
gran desert és una gran ciutat (1986) concentrating on the theme of economic exile to Brazil.

Finally, no work on this subject would be complete without mention of Mercè Rodoreda's war stories, which in combination with her letters to Anna Murià constitute a moving memorial to the period, and of Montserrat Roig, whose work spans the gamut of fiction, chronicle, journalism, and testimonial. Since both of these authors have been studied, there is no need to repeat what others have said, but I will close by pointing out the excellent study of Roig by Christina Dupláa, La voz testimonial de Montserrat Roig (1996), in which the scholar examines Roig's efforts to give voice to the silenced, to rewrite history from the point of view of the conquered. The continuum between history and literature is expressed succinctly by one of Roig's characters in her novel, L'bora violeta (1980): "Car el temps de la memòria no té res a veure amb el temps de la història...L'ordre de la imaginació s'escapa a totes les dades, a tots els fets. Aquesta és la revenja de la literatura contra la Història." (8g)

KATHLEEN McNERNEY
WEST VIRGINIA UNIVERSITY

\section{WORKS CITED}

AngladA, Maria Àngels. Les closes. Barcelona: Destino, 1979.

CAPMANY, Maria Aurèlia. Lo color més blau. Barcelona: Planeta, I982. -. Quim/Quima. Barcelona: Laia, I971.

DuplaA, Christina. La voz testimonial en Montserrat Roig. Barcelona: Icaria,1996.

HART, Patricia. "Translator's Afterword: Rage Against the MachineHistory Disobeyed, Justice Delayed and Cinderella Spayed in Isabel-Clara Simós Júlia." In Julia: A Critical Edition. Ed. and trans. Patricia Hart. New Orleans: UP of the South, 1998: 173-187. Herzberger, David K. Narrating the Past; Fiction and Historiography in Postwar Spain. Durham and London: Duke U $\mathrm{P}, 1995$.

Marçal, Maria-Mercè. La passió segons Renée Vivien. Barcelona: Columna Proa, 1995.

MarTín GAITE, Carmen. El cuarto de atrás. Barcelona: Destino, 1978.

-. Usos amorosos de la postguerra española. Barcelona: Anagrama, 1987.

Mestre, Cassandra. Arreu la sorra. Barcelona: El Llamp, 1986. 
MontSenY, Frederica. Cent dies de la vida d'una dona (1939-40). Barcelona: Galba, 1977.

MuriA, Anna. Aquest serà el principi. Barcelona: laSal, 1986.

-. and Quirze Grifell. Anna Muriè, Album de records. Argentona: L'Aixemador, 1992.

PAmies, Teresa. Rebelión de viejas. Barcelona: laSal, 1989.

RIERA, Carme. Dins el darrer blau. Barcelona: Destino, 1994.

- "Helena, Helena." In Jo pos per testimoni les gavines. Barcelona: Laia, 1977: 27-37.

-. "La senyoreta Angels Ruscadell investiga la terrible mort de Marianna Servera." In Epitelis tendrissims. Barcelona: Eds, 62, 1981: 97-IIO.

RODOREDA, Mercè. Cartes a l'Anna Murià: 1939-1956. Barcelona: laSal, 1985.

-. Tots els contes. Barcelona: Eds. 62, 1979.

RoIG, Montserrat. L'hora violeta. Barcelona: Eds. 62, 1980.

Rossello, Anna and Josep Travesset. El més gran desert és una gran ciutat. Barcelona: El Llamp, 1986.

Simö, Isabel-Clara. Júlia. Barcelona: Magrana, 1983.

UGARTE, Michael. Shifting Ground: Spanish Civil War Exile Literature. Durham and London: Duke UP, 1989.

-. "Women, War, and Exile: Anna Murià's Aquest serà el principi." Catalan Review XI. I-2 (1997): 125-39.

VAYREDA, Maria dels Àngels. Encara no sé com sóc. Barcelona: Club, I985.

WoOLf, Virginia. Orlando: A Biography. London: Harvest, 1928. 